\title{
Flowability and physical properties of wheat-unripe plantain (Musa paradisiaca) composite flour
}

\author{
${ }^{1}$ Etti, C.J., ${ }^{2,3 *}$ Yusof, Y.A., ${ }^{4}$ Chang, L.S. and ${ }^{1}$ Ekanem, V.G. \\ ${ }^{1}$ Department of Agricultural and Food Engineering, Faculty of Engineering, University of Uyo, Uyo, \\ Nigeria \\ ${ }^{2}$ Department of Process and Food Engineering, Faculty of Engineering, Universiti Putra Malaysia, 43400, \\ UPM Serdang, Selangor, Malaysia. \\ ${ }^{3}$ Laboratory of Halal Services, Halal Products Research Institute, Universiti Putra Malaysia, 43400 \\ Selangor, Malaysia \\ ${ }^{4}$ Department of Food Science Faculty of Food Science and Technology, Universiti Putra Malaysia, 43400, \\ UPM Serdang, Selangor, Malaysia.
}

\section{Article history: \\ Received: 25 June 2018 \\ Received in revised form: 5 October 2018 \\ Accepted: 27 October 2018 \\ Available Online: 6 \\ November 2018 \\ Keywords: \\ Wheat flour, \\ Unripe plantain flour, \\ Composite flour, \\ Flowability, \\ Density, \\ Iron content}

DOI:

https://doi.org/10.26656/fr.2017.3(2).129

\begin{abstract}
This study investigated the flowability and physical properties of composite flour made from wheat flour mixed with unripe plantain flour at different ratios (70:30, 80:20 and 90:10, respectively and 100\% wheat flour as control). Unripe plantain flour was chosen because it has high iron content which can resolve diet issues encountered by anaemic and celiac patients due to low iron and high protein (gluten) content in consumption of wheat bread. Physical properties of the composite flour were determined: bulk density, tapped density, angle of repose, and flowability. The proximate analysis such as ash, lipid, fibre, carbohydrate, protein, moisture content of the mixed flour was determined as well as iron content. The density of the composite flour was increased as the unripe plantain flour in the mix ratio increased, suggesting that unripe plantain flour was denser than the substituted wheat flour. The flow indexes of the composite flours show excellent freeflowing behaviour as the Carr Index $(C I)$ and Hausner Ratio $(H R)$ were within the range of the powder that exhibited free-flowing properties. The use of plantain flour increased the proximate composition of the composite flour except for protein content which is advantageous to the celiac patients who do not need much of the bread protein (gluten). The iron content was increased with the increase of unripe plantain flour in the mix ratio, favouring anaemic patients who require more iron. Incorporation of higher amount of unripe plantain flour reduced the swelling power of the dough which affected the bread making process.
\end{abstract}

\section{Introduction}

Composite flour technology is gaining much ground and drawing greater attention from the researchers, principally in the development of bakery products such as bread and other pastries (Noorfarahzilah et al., 2014). Wheat and non-wheat flour blends for composite bread production are advantageous especially for the developing nations due to economic concerns. In this case, the importation of wheat flour is controlled and the usage of locally grown non-wheat nutritionally supplemented crops are encouraged in such developing nations (Hugo et al., 2003). Generally, wheat is nutritionally poor as it is deficient in essential amino acids and it is, therefore, being supplemented with inexpensive staple crop to improve the nutritional quality of the composite products (Sharma et al., 1999; Dhingra and Jood, 2001). Some individuals are intolerant to 100 $\%$ gluten of wheat and hence, the need to develop alternative gluten-reduced flours have been encouraged (Adegunwa et al., 2017).

Plantain flour (Musa paradisiaca) is a good supplement with wheat flour for baking because it has high water absorption capacity and therefore can be considered as a good functional agent in baking (Akubor, 1998). Nigeria is regarded as one of the principal countries in plantains production in the world (FAO, 2006). However, about $40-60 \%$ post-harvest losses had been reported and losses are accredited to poor storage 
facilities and poor technologies for food processing (FAO, 2009). Also, feeding principally on plantain cannot meet up with the daily protein requirement, therefore protein supplementation with wheat flour is essential (Ogazi et al., 1996). Composite bread generally needs at least $70 \%$ of wheat flour to be able to form leavened products (FAO, 1979; Eggleston, 1993). The investigation on the need to apply whole plantain flour in baking and confectioneries with respect to their pasting properties was conducted (Abiodun-Solanke and Falade, 2010). A proper understanding of flowability behaviour of composite flours is necessary to combat problems such as poor quality products that may result from flour flowability (Etti et al., 2014) since flowability can influence the functional properties such as dough swelling power of the composite flour as well as the physical properties of the bread loaves.

Overall, this study is aimed at investigating the flowability and physical properties of wheat-unripe plantain composite flour in bread making, in order to enhance the composite bread quality and also to improve the nutritional status of the bread. This study was beneficial especially for anaemic and celiac patients who need to consume bread that can improve their low blood status while taking as low gluten level as possible by taking the wheat-unripe plantain composite bread.

\section{Materials and methods}

\subsection{Materials}

Commercially available all-purpose wheat and plantain flours, table salt, granulated sugar (Dangote Groups, Nig. Ltd, Lagos, Nigeria) used were purchased from Nteps Shopping Mall in Uyo, Akwa Ibom State, Nigeria. Butter, dry baker's yeast and milk were obtained from Akpan Andem Main Market, Uyo, Akwa Ibom State, Nigeria.

\subsection{Preparation of flour}

Mature wholesome plantain fingers were peeled, washed and cut into thin slices of about $2 \mathrm{~cm}$ thick and spread without overlapping in a wire gauge. The slices were drained and dehydrated in an air circulating dryer at $60^{\circ} \mathrm{C}$ for $48 \mathrm{hrs}$. Dried plantain flour was milled into flour using a Syinix blender BLNPPK-202. Flour obtained was sifted through a $250 \mu \mathrm{m}$ aperture sieve in microwaveable plates. The composite flour was prepared using the ratios of 90:10, 80:20, 70:30, wheat: unripe plantain composite flour, with $100 \mathrm{~g}$ wheat flour serving as the control.

\subsection{Bulk and tapped densities}

Bulk density $\left(p_{\mathrm{b}}\right)$ can be identified as the ratio of the weight of powder bed in a vessel to the volume of the powder occupied in the bed before tapping. Whereas, tap density is a different type of bulk density obtained by tapping or vibrating the container in a particular method to achieve more effective particle parking and therefore, it is usually higher than bulk density (Lowell and Shields, 1984);

$$
\rho_{b}=\left(\frac{W_{t}}{V_{b}}\right)
$$

Where $\mathrm{W}_{\mathrm{t}}$ is the weight of the powder; and $\mathrm{V}_{\mathrm{b}}$ is the volume of the powder obtained from tarred graduated cylinder without tapping. The tapped density ( $\left.p_{\text {tap }}\right)$ of the powders was calculated by using the following equation;

$$
\rho_{\text {tab }}=\left(\frac{W_{t}}{v_{\text {tap }}}\right)
$$

Where $\mathrm{W}_{\mathrm{t}}$ is the weight of powder; and $\mathrm{V}_{\text {tap }}$ is the volume of the powder bed after 500 taps.

\subsection{Carr index and Hausner ratio}

Carr Index and Hausner ratio were used in describing the flow indexes and flowability of powder. Carr Index $(C I)$ can be determined as the ratio of the difference of the tapped and the bulk densities to the tapped density (Carr, 1965). According to Carr (1965), who introduced the flowability index, an excellent flowability is between the Carr Index of 5\% to $15 \%$ while Carr Index of above $25 \%$ normally shows poor flowability.

$$
C I=\frac{\rho_{\text {tap }}-\rho_{t}}{\rho_{\text {tah }}}
$$

Hausner Ratio $(H R)$ was also used to characterize the flowability of the powder, which can be determined by the ratio of the tapped density to that of bulk density (Hausner, 1967).

$$
H R=\frac{\rho_{\text {tap }}}{\rho_{b}}
$$

According to (Hayes, 1987), HR between 1.0 and 1.10 shows a powder that is free-flowing, $H R$ between 1.11 and 1.25 shows a powder that is considered to be medium flowing. When the $H R$ is between 1.26 and 1.4, the powder is considered to be difficult to flow, and for $H R$ greater than 1.4 , the powder is considered to be very difficult to flow.

\subsection{Angle of repose}

Angle of repose is the same as angle of internal friction under the loosest packing condition (Metcalf, 1966). The measurement of the angle of repose $\left(\theta_{R}\right)$ was done using a static and loose base piling method. The bottom stem of a funnel was positioned $6 \mathrm{~cm}$ above a horizontal. The stem opening of the funnel was initially blocked with a finger before approximately $60 \mathrm{~g}$ of powder was put into the funnel. The powder was 
thereafter carefully discharged directly beneath onto the horizontal base to form a heap by unblocking the stem of the funnel opening. The measurement of the angle between the heap with respect to the horizontal using the protractor was taken as the angle of repose. The experiment was done in triplicate for each powder and the average value was recorded (Metcalf, 1966).

$$
\theta_{R}=\tan ^{-1} \frac{2 H}{D}
$$

Where, $\theta_{\mathrm{R}}=$ Angle of repose $\left({ }^{\circ}\right) ; H=$ Height of the pile (m); and $D=$ Diameter of the pile (m)

\subsection{Moisture content}

The moisture content of the flour was determined with the use of a digital moisture analyzer (OHAUS MB45, UK) set at $105^{\circ} \mathrm{C}$. The flour was weighed to $3.00 \pm 0.01 \mathrm{~g}$ in a sample plate and measurements were made in triplicate. The moisture analyser was allowed to cool between tests for each powder.

\subsection{Proximate composition}

Proximate composition of the samples was carried out using official AOAC (1984) methods for moisture content, crude fat, crude fibre, ash, crude protein. Nitrogen to protein conversion factor of 6.25 was used. Carbohydrate content was calculated by difference.

\subsection{Iron content}

The iron content of the bread was determined by using the bread ash earlier used. The ash was placed in porcelain crucibles, then few drops of distilled water were added, followed by $2 \mathrm{~mL}$ of concentrated $\mathrm{HCl}$. $10 \mathrm{ml}$ of $20 \% \mathrm{HNO}_{3}$ was added, then evaporated on a hot plate. The samples were then filtered through a Whatman filter paper into $100 \mathrm{ml}$ volumetric flask. The mineral element, iron was determined by atomic absorbance spectrophotometer (AOAC, 2005).

\subsection{Bread production by the straight dough method}

The straight dough method was used to prepare the bread. This method involves the addition of all the ingredients (flour, salt, water, sugar, yeast, etc.) at the mixing stage and kneading same to obtain the dough (Gisslen, 2012). The different dough samples made from different ratio of wheat: unripe plantain flour was placed in baking pans smeared with butter and covered with polythene for the dough to ferment resulting in gas production and gluten development enabling the dough to rise for about an hour as this shows the swelling power of the dough whose height was measured with venire calliper in mill-meter (Table 3). The dough was then baked in an oven at $230^{\circ} \mathrm{C}$ for 30 mins. The baked loaves were removed from the pans and allowed to cool for analysis.

\section{Results and discussion}

\subsection{Physical properties of flour}

The physical properties of the composite flours are presented in Table 1. The densities of the composite flours were increased as the unripe plantain flour in the mix ratio increased. Bulk density and tapped density were increased by up to $39.9 \%$ and $39.6 \%$, respectively when the unripe plantain flour used was increased from 0 to $30 \%$. This suggests that unripe plantain flour was denser than the substituted wheat flour; hence, showing that composites with greater amounts of plantain flour pack better.

Table 1 also shows the results of angle of repose $\theta_{R}$ $\left(^{\circ}\right)$ with all the composite flours having small $\theta_{R}$ of not more than $30^{\circ}$. The unripe plantain composite flour exhibited the lowest $\theta_{\mathrm{R}}$ which was $27^{\circ}$. Generally, the result of the angle of repose was in line with the flowability result which confirmed that all the composite flours were "free-flowing", with smaller angle of repose, since angle of repose is also an indicator to measure flowability behaviour (Jenike and Johanson, 1969).

The flowability measurements of the composite flours was determined from the densities (tapped and bulk) parameters, by calculating for the percentage Carr (1965) index and Hausner (1967) ratio for the flours. The flowability behaviour of the flour was categorized based on categorization scale according to Hayes (1987). From the results in Table 1, all the composites flours were expected to be "free-flowing" as the Carr index $(\% C I)$ and Hausner ratio $(H R)$ was between the range of 2.2 $( \pm 0.1)$ to $6.3( \pm 0.5) \% C I$ and $1.02( \pm 0.04)$ to $1.07( \pm 0.08)$ $H R$ from wheat-unripe plantain flour composite ratio of 0:100 and 100:0, respectively (Table 1 ). According to Carr (1965), the flowability index of flour (powder) is known to be excellent flowability, if the $C I$ is between 5 and $15 \%$. Meanwhile, $C I$ above $25 \%$ shows "poor flowability". Also, the powder is considered as "freeflowing" if the $H R$ is between 1.0 and 1.1. If the $H R$ is greater than 1.1 to 1.25 , the powder is classified as "medium flowing". Meanwhile, if $H R$ is greater than 1.25 to 1.4 , the powder is classified as "difficult to flow" and if $H R$ is higher than 1.4, the powder is considered to be "very difficult to flow" (Hayes, 1987). Hence, in this study, all the composite flours exhibited free-flowing behavior regardless of the ratio of wheat flour and unripe plantain flour used.

\subsection{Proximate composition and iron content}

The proximate composition of the composite flours is presented in Table 2. The results showed that an 
Table 1. Physical properties of the composite flours

\begin{tabular}{ccccccc}
\hline $\begin{array}{c}\text { Wheat: unripe } \\
\text { plantain flour }\end{array}$ & $\begin{array}{c}\text { Bulk density } \\
\left(\mathrm{kg} / \mathrm{m}^{3}\right)\end{array}$ & $\begin{array}{c}\text { Tapped density } \\
\left(\mathrm{kg} / \mathrm{m}^{3}\right)\end{array}$ & $\begin{array}{c}\text { Angle of } \\
\text { repose } \theta_{\mathrm{R}}\left({ }^{\circ}\right)\end{array}$ & $\begin{array}{c}\text { Carr index } \\
(1965) \mathrm{CI} \%\end{array}$ & $\begin{array}{c}\text { Hausner ratio } \\
(1967) \text { HR }\end{array}$ & $\begin{array}{c}\text { Flowability } \\
\text { behaviour }\end{array}$ \\
\hline $100: 0$ & $450.7 \pm 1.2$ & $480.1 \pm 2.3$ & $30.0 \pm 0.0$ & $6.3 \pm 0.5$ & $1.07 \pm 0.08$ & Free-flowing \\
$90: 10$ & $460.1 \pm 2.5$ & $490.2 \pm 3.2$ & $29.5 \pm 0.0$ & $6.1 \pm 0.2$ & $1.07 \pm 0.09$ & Free-flowing \\
$80: 20$ & $470.3 \pm 1.4$ & $500.5 \pm 3.0$ & $29.0 \pm 0.0$ & $6.0 \pm 0.5$ & $1.06 \pm 0.03$ & Free-flowing \\
$70: 30$ & $630.7 \pm 0.8$ & $670.3 \pm 4.1$ & $28.0 \pm 0.0$ & $5.9 \pm 0.8$ & $1.06 \pm 0.01$ & Free-flowing \\
$0: 100$ & $890.5 \pm 1.6$ & $910.8 \pm 2.2$ & $27.0 \pm 0.0$ & $2.2 \pm 0.1$ & $1.02 \pm 0.04$ & Free-flowing \\
\hline
\end{tabular}

(* Standard deviation values are placed in the bracket, flow characteristic was from categorization scale based on Hayes, 1987)

Table 2. Proximate composition and iron content composition of the composite flours

\begin{tabular}{|c|c|c|c|c|c|c|c|}
\hline $\begin{array}{l}\text { Wheat: unripe } \\
\text { plantain flour }\end{array}$ & Ash (\%) & Lipid (\%) & Fibre (\%) & $\begin{array}{c}\text { Carbohydrate } \\
(\%)\end{array}$ & Protein $(\%)$ & $\begin{array}{c}\text { Moisture } \\
\text { content }(\% \\
\text { dry basis })\end{array}$ & $\operatorname{Iron}(\mathrm{mg} / \mathrm{l})$ \\
\hline $100: 0$ & $1.46 \pm 0.11$ & $2.70 \pm 0.11$ & $2.80 \pm 0.11$ & $73.68 \pm 0.02$ & $13.26 \pm 0.01$ & $6.1 \pm 0.2$ & $2.72 \pm 0.14$ \\
\hline $90: 10$ & $2.18 \pm 0.11$ & $3.00 \pm 0.11$ & $5.09 \pm 0.04$ & $74.15 \pm 0.03$ & $8.33 \pm 0.12$ & $7.3 \pm 0.2$ & $8.53 \pm 0.13$ \\
\hline $80: 20$ & $2.58 \pm 0.11$ & $3.50 \pm 0.11$ & $5.52 \pm 0.11$ & $74.60 \pm 0.02$ & $6.15 \pm 0.10$ & $7.7 \pm 0.9$ & $9.63 \pm 0.11$ \\
\hline $70: 30$ & $2.80 \pm 0.11$ & $3.65 \pm 0.11$ & $5.82 \pm 0.00$ & $75.28 \pm 0.00$ & $4.65 \pm 0.03$ & $7.8 \pm 0.3$ & $9.74 \pm 0.04$ \\
\hline $0: 100$ & $3.36 \pm 0.01$ & $3.80 \pm 0.03$ & $6.51 \pm 0.11$ & $76.03 \pm 0.02$ & $2.30 \pm 0.03$ & $8.0 \pm 0.2$ & $12.00 \pm 0.15$ \\
\hline
\end{tabular}

increase of ash content in the composite flour samples per increased in plantain flour. The highest ash content was recorded in composite flour of 0: 100 (wheat flour: unripe plantain) which was $3.36( \pm 0.01) \%$, showing that plantain flour has more ash content than wheat flour. This result is in agreement with the investigation of Ahmad et al. (2001) where low ash content was reported in the quality characteristics of different wheat varieties grown in Pakistan. Ash content is a reflection of the mineral matter in a food sample (Iwe et al., 2017). High ash content in plantain flour suggesting it contains high mineral matter.

The lipid content showed an increased per substitutions of more unripe plantain flour where the lipid content increased by up to $35 \%$ when plantain flour used was increased by $30 \%$. The highest lipid content was recorded in $100 \%$ of plantain flour. This reveals that wheat flour has less lipid content than plantain flour. Besides, the fibre content of unripe plantain contained the highest fibre value $(6.51 \pm 0.11 \%)$ while the wheat flour had the lowest fibre content $(2.80 \pm 0.11 \%)$, indicating plantain flour contains high fibre content. Consequently, there was an increase in fibre content with the increase of plantain flour substitutions. The carbohydrate content was calculated by difference showed an increase with substitutions of more plantain flour. The protein content for $100 \%$ wheat flour with a value of $13.26 \%$ was remarkably massive, but there was a sharp decrease in protein content for $100 \%$ unripe plantain flour with a value of $2.30 \%$. A decrease in protein content with substitutions of more plantain flour is sufficiently good to make it as a recommendation for bread making. This is because it can be used to substitute part of the wheat flour in bread making as celiac patients do not require much protein from high gluten contents bread (Adegunwa et al., 2017). In addition, the result of moisture content did not really influence the flowability of the composite flours (Table 1) as the moisture content was low, ranging from $6.1( \pm 0.2) \%$ of 100 : 0 wheatunripe plantain composite flours to $8.0( \pm 0.2)$ of $0: 100$ of wheat-unripe composite flours. Increasing moisture content may make flour not free-flowing (cohesive); however, exceeding certain moisture contents the moisture may act as lubricant thus improving the flour (powder) flowability (Mohsenin, 1986).

The iron content of the composite flour is shown in Table 2. The highest iron content was recorded in $100 \%$ of unripe plantain flour which was about $12.00 \mathrm{mg} / \mathrm{l}$. Meanwhile, the lowest value of iron content was found in $100 \%$ wheat flour which was about $2.72 \mathrm{mg} / \mathrm{l}$. This result suggests that plantain flour can be a good source of iron and incorporation of plantain flour in bread making might improve the iron content in the bread. It also reveals that an increase in the amount of plantain flour in the mix ratio increased the iron contents of the flour. This favours anaemic patience as consumption of bread made from plantain flour that substitutes the wheat flour might help to improve their blood level due to high iron content from plantain flour.

\subsection{Physical properties of flour and dough swelling power relationship}

The wheat: unripe-plantain composite flour was mixed with water, yeast, sugar, margarine and salt according to the method of Uzoukwu et al. (2015) to make the dough. Bread dough is a soft, thick mixture of dry ingredients, such as flour, yeast, water, etc. which is kneaded, shaped, and baked, and has viscoelastic properties. Techniques used in dough production depend on the type of dough and final product expected. For 
yeast-based bread, a common production technique is by ensuring that the dough is mixed, kneaded and then left to rise. The baking quality of the bread is determined by the physical properties of the dough (gliadin to glutenin ratio), its oxidative potential, flour water absorption, bread volume, and colour of crumb and crust (Mepba et al., 2007). Rheological properties of flour dough are vital for the effective production of bakery products as they determine its behaviour during mechanical handling, thereby affecting the quality of the finished products (Hoseney et al., 1988; Weipert, 1992).

Table 3. Dough swelling power

\begin{tabular}{ccccc}
\hline \multirow{2}{*}{$\begin{array}{c}\text { \% wheat: unripe } \\
\text { plantain flour }\end{array}$} & \multicolumn{4}{c}{ Time (min) } \\
\cline { 2 - 5 } & \multicolumn{4}{c}{ Swelling power $(\mathrm{mm})$} \\
\cline { 2 - 5 } $100: 0$ & $7.0 \pm 0.0$ & $4.0 \pm 0.0$ & $2.0 \pm 0.0$ & $1.0 \pm 0.0$ \\
$90: 10$ & $2.5 \pm 0.0$ & $0.0 \pm 0.0$ & $1.0 \pm 0.0$ & $0.2 \pm 0.0$ \\
$80: 20$ & $1.0 \pm 0.0$ & $0.0 \pm 0.0$ & $0.5 \pm 0.0$ & $0.0 \pm 0.0$ \\
$70: 30$ & $1.0 \pm 0.0$ & $0.0 \pm 0.0$ & $-1.0 \pm 0.0$ & $-2.0 \pm 0.0$ \\
$0: 100$ & - & - & - & - \\
\hline
\end{tabular}

Table 3 shows the ability of the dough to rise which is measured by the change in height of the dough at every 15 mins up to $60 \mathrm{mins}(1 \mathrm{hr})$. The incorporation of the unripe-plantain flour substitute affected the ability of the dough to rise as plantain lack of gluten proteins which is responsible for strength and elasticity for the dough rising as a result of yeast fermentation. Hence, the ability to rise of the dough made from the high amount of plantain flour was poor. There was still some level of rise in the composite flours which might be due to the wheat flour component of the mix. The least rise was observed in 70:30 (\% wheat: unripe-plantain) dough sample with $1 \mathrm{~mm}$ rise after 15 mins and thereafter, a decrease in dough height was seen at 45 mins and 60 mins time intervals (Table 3 ). The result shows that increasing levels of plantain flour in bread making decreases the dough height with increasing time interval. This result also shows that the components of the flour influenced the baking qualities of the bread.

\section{Conclusion}

The substitution of wheat flour with different level of unripe plantain flour in bread dough making was achieved. The flowability properties of the composite flours were all free-flowing. The addition of unripeplantain flour to wheat flour increased the proximate composition of the composite flour except for protein content which is advantageous to the celiac patients that do not need much of the bread protein (gluten). The addition of unripe-plantain flour also improved the iron content of the bread and this is good with the anaemic patients who require more blood in their system.
Substitution of wheat flour with some level of unripeplantain flour affected the swelling power (ability to rise) of the dough as the gluten content of the dough was affected. Increasing levels of plantain flour in bread making decreases the dough height with increasing time interval.

\section{References}

Abiodun-Solanke, A.O. and Falade, K.O. (2010). A review of the uses and methods of processing banana and plantain (Musa spp.) into storable food products. Journal of Agricultural Research and Development, 9(2), 85-96.

Adegunwa, M.O., Adelekan, E.O., Adebowale, A.A., Bakare, H.A. and Alamu, E.O. (2017). Evaluation of nutritional and functional properties of plantain (Musa paradisiaca L.) and tigernut (Cyperus esculentus L.) flour blends for food formulations. Cogent Chemistry, 3(1), 1-15. https:// doi.org/10.1080/23312009.2017.1383707

Ahmad, I., Anjum, F.M. and Butt, M.S. (2001). Quality characteristics of wheat varieties grown from 19331996. Pakistan Journal of Food Sciences, 20(1-2), 117.

Akubor, P.I. (1998). Functional properties of cowpeaplantain flour blends. Proceedings: 22nd Annual NIFST Conference, University of Agriculture, Abeokuta. 1998.

AOAC. (1984). Official methods of analysis. Association of official analytical chemists. 14th ed. USA: The William byrd Press.

AOAC. (2005). Official methods of analysis. Association of official analytical chemists. 18th ed., p. 806-842. Arlington, USA: Association of Official Analytical Chemist.

Carr, R.L. (1965). Evaluating flow properties of solids. Chemical Engineering, 72, 163-168.

Dhingra, S. and Jood, S. (2001). Organoleptic and nutritional evaluation of wheat breads supplemented with soybean and barley flour. Journal of Food Chemistry, 77(4), 479-488. https://doi.org/10.1016/ S0308-8146(01)00387-9

Eggleston, G., Omoaka, P.E. and Ihedioha, D.O. (1993). Development and evaluation of products from cassava flour as new alternatives to wheaten breads. Journal of the Science of Food and Agriculture, 59 (3), 377-385. https://doi.org/10.1002/jsfa.2740590315

Etti, C.J., Yusof, Y.A., Chin, N.L. and Mohd Tahir, S. (2014). Flowability properties of Labisia pumila herbal powder. Agriculture and Agricultural Science Procedia, 2, 120-127. https://doi.org/10.1016/ j.aaspro.2014.11.018 
FAO. (1979). Food Outlook. Food and Agriculture Organisation of the United Nations Rome: FAO

FAO. (2009). Food and Agriculture Organisation of the United Nations. Joint meeting of the fourth session of the sub-group on bananas and the fifth session of the sub-group on tropical fruits, 9-11 December 2009. Rome: FAO

FAO. (2006). Food and Agriculture Organisation of the United Nations. The state of food insecurity in the world. Eradicating world hunger-taking stock ten years after the world food summit. Rome: FAO.

Gisslen, W. (2012). Professional baking. $6^{\text {th }}$ ed. New York: John Wiley.

Hausner, H.H. (1967). Friction conditions in a mass of metal powder. International Journal of Powder Metallurgy, 3(4), 7-13.

Hayes, G.D. (1987). Food engineering data handbook, p. 183. New York: Longman scientific and technical.

Hoseney, R.C., Wade, P. and Finley, J.W. (1988). Soft wheat products. In Pomeranz, Y. Wheat: chemistry and technology, p. 407-417. St. Paul, USA: AACC

Hugo, L., Rooney, L. and Taylor, J. (2003). Fermented sorghum as a functional ingredient in composite breads. Cereal Chemistry, 80(5), 459-499. https:// doi.org/10.1094/CCHEM.2003.80.5.495

Iwe, M.O., Michael, N., Madu, N.E., Obasi, N.E., Onwuka, G.I., Nwabueze, T.U. and Onuh, J.O. (2017). Physicochemical and pasting properties high quality cassava flour (HQCF) and wheat flour blends. Agrotechnology, 6(3), 1-8.

Jenike, A.W. and Johason, J.R. (1969). On the theory of bin loads. Journal of Manufacturing Science and Engineering, 91(2), 339.

Lowell, S. and Shields, J.E. (Eds.) (1984). Density measurement. In Powder surface area and porosity, p. 217-221. New York: Chapman and Hall https:// doi.org/10.1007/978-94-009-5562-2_21

Mepba, H., Eboh, L. and Nwaojigwa, S.U. (2007). Chemical composition, functional and baking properties of wheat-plantain composite flours. African Journal Food, Agriculture, Nutrition and Development, 7(1), 1-22.

Metcalf, J.R. (1966). Angle of repose and internal friction. International Journal of Rock Mechanics and Mining Sciences and Geomechanics Abstracts, 3 (2), 155-161. https://doi.org/10.1016/0148-9062(66) 90005-2

Mohsenin, N.N. (1986). Friction physical properties of plant and animal materials. Vol. 1, p. 556-642. New York: Gordon and Breach Publishers.
Noorfarahzilah, M., Lee, J.S., Sharifudin, M.S., Mohd Fadzelly, A.B. and Hasmadi, M. (2014). Applications of composite flour in development of food products. International Food Research Journal, 21(6), 2061-2074.

Ogazi, P.O., Oyewusi, F.A., Ozumba, A.U., Ogundipe, H.O., Osifo, B.O.A. and Lukambi, F.A. (1996). Development and sensory evaluation of soyamusa: A soybean-plantain baby food. ISHS Acta Horticulturae 540: International conference on banana and plantain for Africa. https://doi.org/ 10.17660/ActaHortic.2000.540.63

Sharma, S., Bajwa, U.H. and Nagi, H.P.S. (1999). Rheological and baking properties of cowpea and wheat flour blends. Journal Science Food Agriculture, 79(5), 657-662. https://doi.org/10.1002/ (SICI) 1097-0010(199904)79:5<657::AIDJSFA228 $>3.0 . \mathrm{CO} ; 2-3$

Uzoukwu, A.E., Ubbaonu, C.N., Enwereuzor, R.O., Akajiaku, L.O., Umelo, M.C. and Okereke, S.O. (2015). The functional properties of plantain (Musa sp) flour and sensory properties of bread from wheat - plantain flour as influenced by blanching treatments. Asian Journal of Agriculture and Food Sciences, 3(1), 1-12.

Weipert, D. (1992). Descriptive and fundamental rheometry in a new light. Cereal Food World, 37, 15 -24 . 